\title{
Bibliography of Finnish Population Research 1992-1993
}

\author{
GATHERED AND EDITED BY ULLA-MAIJA MATTILA
}

The bibliography covers mainly the literature on population research published in Finland during 1992-1993. Included are independent publications, articles in periodicals and statistics published in Finland as well as studies by Finnish authors published abroad. In general the bibliography excludes noncientific articles in newspapers and weeklies as well as unpublished reports and academic theses. Also not included are studies presented at proceedings of conferences held in Finland if they were written abroad and treated subjects outside Finland. Neither are comparative studies where Finland not forms a substantial part included in the bibliography. Coverage is less complete in peripheral fields.

In principle the main divisions appearing in the Population Index have been used with added subdivisions better suiting Finnish circumstances. Studies covering several fields of demography, which should rightly be listed in two or more divisions are included in only one division, i.e. in the division representing the primary field, on which the report is centered.

Lists of literature on population research have been published in Yearbooks II-IV of The Family Federation of Finland and since 1960 in the Yearbook of Population Research in Finland, at first every fourth year, then every second year and starting from 1992 every year.

\section{A. GENERAL POPULATION STUDIES AND THEORIES}

Hulkko, Jouko. Maailman väestönkehitys ja sen vaikutuksista (World population development and its effects). Futura, vol. 12, no. 3, 1993, 51-56 pp. Sum in Eng.

Majava, Altti. Ihmiskunnan kasvukivut (Growing pains of mankind). Futura, vol. 12, no. 3, 1993, 45-50 pp. Sum in Eng.

Uitto, J.I. Population geography cannot afford to neglect the burning problems facing mankind. In: Where is population geography going?, edited by Daniel Noin. 1991. 10-12 pp. International Geographical Union, Commission on Population Geography, Paris.

\section{B. REGIONAL POPULATION STUDIES}

Karjalainen, Elli. Differentiation of rural areas in Kainuu, Finland. Yearbook of Population Research in Finland, vol. 30, 1992, 81-94 pp.

\section{SPATIAL DISTRIBUTION}

Jakobson, Leo. Suomen kaupungistuminen: vertailu kansainväliseen kehitykseen ja kehityspoliittiset mahdollisuudet (The urbanization of Finland: comparison with the international development and development political possibilities). $1992.110+24$ pp. Suomen kaupunkiliitto, Helsinki. ISBN 951-759-835-1.

Peltola, Olli. Suomen suurimpien kaupunkiseutujen väestönmuutokset 1975-1990 (Population changes of the biggest urban regions in Finland 1975-1990). Proceedings of the University of Vaasa, Discussion papers, no. 144. 1992. $18+2$ pp. Vaasan yliopisto, Vaasa. ISBN 951683-430-2. Sum in Eng.

Peltola, Olli. Suomen yhdyskuntajärjestelmän muutos 1980-luvulla (Change of the Finnish settlement system in the 1980s). Proceedings of the University of Vaasa, Discussion Papers, no. 153. 1992. $21+2$ pp. Vaasan yliopisto, Vaasa. ISBN 951-683-451-5. Sum in Eng.

Peltola, Olli. Suomen yhdyskuntajärjestelmän rakenne lääneittäin 1990 (Structure of the settlement system of Finland, by provinces, in 1990). Proceedings of the University of Vaasa, Discussion papers, no. 158. 1993. $15+$ 2 pp. Vaasan yliopisto, Vaasa. ISBN 951-683472-8.

Reijo, Marie. Suomalaisten kaupunkiyhdyskuntien väestönkehitys 1975-2010 (The population development of the Finnish urban areas in 1975-2010). Suomen Väestötieteen Yhdistyksen julkaisuja, no. 13. Yhdyskuntien tuleva kehitys -tutkimusohjelma. 1993. 180 pp. Helsinki. ISBN 951-95357-4-8.

Reijo, Marie; Valkonen, Tapani. Suomalaisten kaupunkiyhdyskuntien väestönkehitys ja taloudellinen rakennemuutos (The Population development and change in the economic struc- 
ture of Finnish urban areas). Yhteiskuntasuunnittelu, vol. 30, no. 4, 1992, 40-55 pp.

Reijo, Marie; Valkonen, Tapani. Population development and the changes in the economic structure of Finnish urban areas. Yearbook of Population Research in Finland, vol. 31, 1993, 25-46 pp.

Seppelin, Markus. Asuntokunnat ja asuntokannan rakenne kaupunkiyhdyskunnissa 1975-1989 (Household size and the housing base in urban areas in 1975-1989). Working papers, no. 56. Yhdyskuntien tuleva kehitys -tutkimusohjelma. 1992. 63 pp. Department of Sociology, University of Helsinki, Helsinki.

\section{TRENDS IN POPULATION GROWTH AND SIZE}

Finnäs, Fjalar. Kommunvisa befolkningsprojektioner med språklig uppdelning 19902020 (Population projections by municipality and by language 1990-2020). Forskningsrapport, no. 21. 1993. 62 pp. Institutet för finlandssvenska samhällsforskning, Vasa.

Jutikkala, Eino. Väkiluvun kasvun markkinarako (A timely period for population growth). In: Suomalaisten tarina, 1. Heräämisen aika 1860-1900, edited by Jaakko Itälä et.al. 1993. 60-63 pp. Kirjayhtymä, Helsinki. ISBN 951-263830-4.

Jutikkala, Eino. "Väestöllisen muuntumisen" ensimmäinen porras (The first stage of "the demographic transition"). In: Suomalaisten tarina, 2. Etsijäin aika 1901-1936, edited by Jaakko Itälä et.al. 1993. 15-18 pp. Kirjayhtymä, Helsinki. ISBN 951-26-3831-2.

Lindgren, Jarl. Suomen väestönkehitys (Development of the population of Finland). Futura, vol. 12, no. 3, 1993, 61-64 pp. Sum in Eng.

Lutz, Wolfgang; Prinz, Christopher. Long range population prospects of Finland in the European context. Yearbook of Population Research in Finland, vol. 30, 1992, 68-80 pp.

Maanantaiseura. Tulevaisuuskuvia Suomen väestörakenteesta (Projections on the population structure of Finland). Maanantaiseuran julkaisuja, no. 1, 1992. 48 pp. ISBN 951-37-0996-5.

Nieminen, Mauri. Suomen väestönkehitys haaste yhteiskunnalle! (Population development in Finland - a challenge for society!). TTT Katsaus, vol. 20, no. 4, 1992, 3-13 pp.

Nieminen, Mauri. Population development in Finland - a challenge for society! Yearbook of Population Research in Finland, vol. 31, 1993, 5-15 pp.

Notkola, Veijo. Namibia - Afrikan mallimaa? (Namibia - a model country for Africa?). Futura, vol. 12, no. 3, 1993. 57-60 pp. Sum in Eng.

Pennanen, Vuokko. Lapin väestö ja työvoima 2030 : tulevaisuusprojektin visiot ja laskelmat (The population and labor of Lapland 2030: visions and calculations of the projec- tion). Sarja A, no. $114,1991.87+21$ pp. Lapin seutukaavaliitto, Rovaniemi. ISBN 951-923673-2.

\section{E. MORTALITY}

Jutikkala, Eino. How many lived to maturity? Yearbook of Population Research in Finland, vol. 31, 1993, 16-24 pp.

Lindeman, Sari; Väisänen, Erkki. Mitä tilastot kertovat suomalaisten ja espanjalaisten itsemurhista? (What the statistics tell about the suicides of the Finns and the Spaniards). Suomen Lääkärilehti, vol. 47, no. 31, 1992, 2935-2937 pp.

Notkola, Veijo; Martikainen, Pekka; Leino, Päivi; Rytkönen, Helena. Metsureiden ja rakennustyöntekijöiden kuolleisuuden kehitys Suomessa 1970-1985 (Trends in mortality among forestry and construction workers in Finland 1970-1985). LEL Työeläkekassan julkaisuja, no. 22. 1992. 21 pp. LEL-työeläkekassa, Helsinki. ISBN 951-96191-9-4.

Pitkänen, Kari J. Deprivation and disease: mortality during the Great Finnish Famine of the 1860s. Publications of the Finnish Demographic Society, no. 14, 1993. 176 pp. Helsinki. 951-95357-5-6. Doctoral dissertation.

Pitkänen, Kari. The patterns of mortality during the great Finnish famine in the 1860 s. In: Acta demographica 1992, edited by Gunter Butler, Gerhard Heilig and Gerhard SchmittRink. 1992. 81-102 pp. Physica-Verlag, Heidelberg, Germany.

Reijo, Marie. Disability and mortality among middle-aged males in counties of Finland in 1975-1988. IIASA working paper, no. WP-92-37. 1992. 31 pp. International Institute for Applied Systems Analysis (IIASA), Laxenburg, Austria.

Valkonen, Tapani; Brancker, Anna; Reijo, Marie. Mortalité differentielle entre trois populations: residents des pays scandinaves, immigrants au Canada d'origine scandinave et residents canadiens nes au Canada (Mortality differentials between three populations-residents of Scandinavia, Scandinavian immigrants to $\mathrm{Ca}$ nada and Canadian-born residents of Canada, 1979-1985). Health Reports, vol. 4, no. 2, 1992. 137-159 pp. In Eng, Fre.

Valkonen, Tapani; Martelin, Tuija; Rimpelä, Arja; Notkola, Veijo; Savela, Soili. Sosioekonomiset kuolleisuuserot 1981-90 (Socio-economic mortality differences in Finland 198190). Population 1992, no. 8. 100 pp. Statistics Finland, Helsinki. ISBN 951-47-6015-8.

Valkonen, Tapani. Trends in regional and socio-economic mortality differentials in Finland. International Journal of Health Sciences, vol. 3, no. 3/4, 1992, 157-166 pp.

Valkonen, Tapani. Problems in the measurement and international comparisons of socioeconomic differences in mortality. Social 
Science and Medicine, vol. 36, no. 4, 1993. 409-418 pp.

Valkonen, Tapani; Martelin, Tuija; Rimpelä, Arja; Notkola, Veijo; Savela, Soili. Socioeconomic mortality differences in Finland 1981-90. Population 1993, no. 1. 100 pp. Statistics Finland, Helsinki. ISBN 951-47-7022-6.

Vuorinen, Heikki. Social variation in infant mortality in a core city of Finland during the 19 th and early 20th centuries. Positive effect of industrialization? Scandinavian Journal of Medicine, vol. 19, no. 4, 1991. 248-255 pp.

Vuorinen, Heikki S. Development of coreperiphery and social differences in children's health in Finland. Kansanterveystieteen julkaisuja, M, no. 109. 1991. $124+45$ pp. Helsinki, University of Helsinki, Department of Public Health. ISBN 951-45-5897-9. Doctoral dissertation.

\section{F. FERTILITY}

El-Khorazaty, Nabil M. Time series analysis of three centuries of the childbearing and fertility process in Finland. Yearbook of Population Research in Finland, vol. 30, 1992, 44 $67 \mathrm{pp}$.

Erkkola, Risto; Kontula, Osmo. Syntyvyyden säännöstely (Birth control). In: Suomalainen seksi: tietoa suomalaisten sukupuolielämän muutoksesta, edited by Osmo Kontula and Elina Haavio-Mannila. 1993. 343-370 pp. WSOY, Porvoo-Helsinki-Juva. ISBN 9510-18672-4.

Karjalainen, Elli. Regional differences and temporal changes of fertility in Finland. In: the geopraphical approach to fertility, edited by Jurgen Bahr and Paul Gans. 1991. 109-119 pp. Universitat Kiel, Geographisches Institut, Kiel, Germany.

Kontula, O.; Rimpelä, M.; Ojanlatva, A. Sexual knowledge, attitudes, fears and behaviors of adolescents in Finland (the KISS study). Health Education Research: Theory and Practice, vol. 7, no. 1, 1992, 69-77 pp.

Kosunen, Elise. Teini-ikäisten raskaudet ja ehkäisy (Teenage pregrancies and contraception). Raportteja, no. 99.81 pp. + app. Helsinki, STAKES Sosiaali- ja terveysalan tutkimusja kehittämiskeskus. ISBN 951-47-7099-4.

Lutz, Wolfgang. Effects of children on divorce probabilities and of divorce on fertility: the case of Finland 1984. Yearbook of Population Research in Finland, vol. 31, 1993, 72 $80 \mathrm{pp}$.

Lähteenmäki, Pekka. Suomalaisen perhesuunnittelun resurssit ja kehitysyhteistyö (Development cooperation and the rescources of Finnish family planning). Futura, vol. 12, no. 3, 65-68 pp. Sum in Eng.

Makkonen, Katri; Hemminki, Elina. Different contraceptive practices: use of contraceptives in Finland and other Nordic countries in the 1970s and 1980s. Scandinavian Journal of Medicine, vol. 19, no. 1, 1991.32-38 pp.

Makkonen, Katri; Hemminki, Elina; Uutela, Antti. Is user's knowledge about contraceptives adequate? A case study of Finnish IUD users. Social Science and Medicine, vol. 35, no. 9, 1992. 1131-1136 pp.

Maunula, Minna. Nuoret ja kondomi: selvitys nuorten ehkäisyyn liittyvistä tiedoista, taidoista ja toiveista (The young and the condom: study on the knowledge, skills and wishes of the young concerning contraception). 1992. 42 pp. + app. Väestöliitto, Väestöntutkimuslaitos.

Myhrman, Antero. Unwanted pregnancy, its occurrence and significance for the family and the child. Acta Universitatis Ouluensis, series D, medica, 249. 1992. $114 \mathrm{pp}$. University of Oulu, Oulu. Doctoral dissertation.

Notkola, Irma-Leena. Raskaudet ja lasten syntymät naisten elämänhistoriassa (Pregnancies and births in the life histories of women). Sum in Fin, Swe and Eng. In: STAKES, 1993. 71-87 pp. Helsinki.

Raitis, Riikka; Saarinen, Riitta. Fertility and family planning in India and Kenya. Yearbook of Population Research in Finland, vol. 30, 1992, 95-103 pp.

Rasimus, Anja. Tilastoja raskauden keskeytyksistä (Statistics on abortions). Sum. in Fin, Swe and Eng In: STAKES, 1993. 21-62 pp. Helsinki.

Rimpelä, Arja H.; Rimpelä, Matti K.; Kosunen, Elise. Use of oral contraceptives by adolescents in Finland in 1981-91. British Medical Journal, vol. 305, no. 6861, 1992. 1053$1057 \mathrm{pp}$.

Rimpelä, Matti; Kontula, Osmo; Notkola, Irma-Leena. Suomalaisia mielipiteitä raskauden keskeytyksestä (Finnish opinions on abortions). Aiheita, no. 34. 1993. 42 pp. Helsinki, STAKES Sosiaali- ja terveysalan tutkimus- ja kehittämiskeskus.

Ritamies, Marketta. Have the aims of the Finnish abortion law been reached? Yearbook of Population Reseach in Finland, vol. 31, 1993, 62-71 pp.

Ritamies, Marketta. Abortti- ja syntyvyyskeskustelun kehityslinjoista (Trends of discussion concerning abortion and fertility in Finland). Sum in Fin, Swe and Eng. In: STAKES, 1993. 11-19 pp. Helsinki.

Ritamies, Marketta. Finland reduces need for abortion. Planned Parenthood in Europe, vol. 22, no. 3, 1993, 11-13 pp.

STAKES. National Research and Development Centre for Welfare and Health. Raskauden keskeytykset vuoteen 1991 Suomessa $=$ avbrytanden av graviditet i Finland till år 1991 = induced abortions in Finland until 1991. Official Statistics of Finland. Health 1993, no 3. 87 pp. Helsinki. Sum in Fin, Swe and Eng. ISBN 951-47-7704-2. 
Teperi, Juha; Keskimäki, Ilmo; Aro, Seppo. Raskaudenkeskeytykset ja sosioekonominen asema (Induced abortion and socioeconomic status). Sum in Fin, Swe and Fin. In: STAKES, 1993. 63-68 pp. Helsinki.

\section{G. NUPTIALITY AND THE FAMILY}

Csernák, Magdolna. Patterns of first marriage in Finland and Hungary: a comparative study. Yearbook of Population Research in Finland, vol. 30, 1992, 18-32 pp.

Finnäs, Fjalar. Formation of unions and families in Finnish cohorts born 1938-67. Studies, no. 197, 1993. 55 pp. Helsinki, Statistics Finland. ISBN 951-47-7033-1.

Haavio-Mannila, Elina. Yhteiskunnan ja parisuhteen muutos (The change in society and in family forms). In: Suomalainen seksi: tietoa suomalaisten sukupuolielämän muutoksesta, edited by Osmo Kontula and Elina-Haavio Mannila. 1993. 35-49 pp. WSOY, Porvoo-Helsinki-Juva. ISBN 951-0-18672-4.

Hulkko, Jouko. Perhe oli omavarainen työyhteisö (Family was a self-sufficient work community). In: Suomalaisten tarina, 1. Heräämisen aika 1860-1900, edited by Jaakko Itälä et.al. 1993. 69-76 pp. Kirjayhtymä, Helsinki. ISBN 951-26-3830-4.

Hulkko, Jouko. Ydinperheen rakkausavioliitto (Nuclear family grounded on love). In: Suomalaisten tarina, 2. Heräämisen aika 19011936, edited by Jaakko Itälä et.al. 1993. 23-28 pp. Kirjayhtymä, Helsinki. ISBN 951-26-38312.

Lindgren, Jarl; Ritamies, Marketta; Miettinen, Anneli. Consensual unions and their dissolution among Finnish women born in 19381969. Yearbook of Population Research in Finland, vol. 30, 1992, 33-43 pp.

Lindgren, Jarl; Ritamies, Marketta; Miettinen, Anneli. Consensual unions and fertility. Yearbook of Population Research in Finland, vol. 31, 1993, 47-61 pp.

Nerdrum, Monica. Gift eller ogift?: åländska kvinnors giftermålsmönster (Married or single?: marriage patterns of the women in the Åland Islands). Budkavlen, vol. 70, 1991, 42$52 \mathrm{pp}$.

Nieminen, Armas. Suomalaisen aviorakkauden ja seksuaalisuuden historia: avioliitto- ja seksuaalikysymyksiä suomalaisen hengenelämän ja yhteiskunnan murroksessa sääty-yhteiskunnan ajoilta nykypäivään (A history of Finnish marital love and sexuality: questions of marriage and sexuality from the period of class society to the present day). Väestöntutkimuslaitoksen julkaisusarja D, no. 27. Helsinki, Väestöliitto, Väestöntutkimuslaitos.

Nikander, Timo. Naisen elämänkulku ja perheellistyminen: the woman's life course and the family formation. Population 1992, no. 1. 172 pp. Statistics Finland, Helsinki. ISBN 951-475388-7.

Nikander, Timo. Suomalaisnaisen perheellistyminen (Family formation of the Finnish woman). Population 1992, no. 10.53 pp. Statistics Finland, Helsinki. ISBN 951-47-6017-4.

Saari, Matti. The development of family structure in Finland in 1960-1987. Yearbook of Population Research in Finland, vol. 30, 1992, 5-17 pp.

\section{H. MIGRATION}

\section{International migration}

Björklund, Krister. Migration in Japan. Siirtolaisuus, vol. 20, no. 3, 16-21 pp.

Domander, Minna. Maahanmuuttajat ja koulutus (Immigrants and education). Siirtolaisuustutkimuksia, no. A16. 1992. 143 pp. Siirtolaisuusinstituutti, Turku. ISBN 951-9266-44-5.

Engman, Max. Finland och utvandringen (Finland and emigration). Siirtolaisuus, vol. 19, no. 2, 1992, 5-15 pp.

Korkiasaari, Jouni. Siirtolaisia ja ulkosuomalaisia: Suomen siirtolaisuus ja ulkosuomalaiset 1980-luvulla (Migration in Finland and expatriate Finns in the 1980's). Työpoliittinen tutkimus, no. 33. 1992.155 pp. Työministeriö, Helsinki. Sum in Fin, Swe and Eng. ISBN 951-47-6820-5.

Korkiasaari, Jouni. Siirtolaisuus- ja ulkomaalaistilastot (Statistics on migration and aliens). Siirtolaisuus, vol. 20, no. 3, 22-25 pp.

Kultalahti, Olli. Maassamuuton ja kansainvälisen muuton viimeaikaisia trendejä (Recent trends of internal and international migration). Siirtolaisuus, vol. 19, no. 4, 1992, 10-21 pp.

Leitzinger, Antero. Ulkomaalaiset Suomessa - johdantoa immigraatiohistoriaamme (Foreigners in Finland - about our immigration history). Siirtolaisuus, vol. 19, no. 4, 1992, 2731 pp. Sum in Eng.

Ojala, Toini. De evakuerade karelernas sociala rörlighet (The social mobility of the evacuated Karelians). Siirtolaisuus, vol. 19, no. 3, 1992, 6-20 pp.

Roinila, Mika. The Atlantic Finns; A forgotten ethnic minority. Siirtolaisuus, vol. 19, no. 1, 1992, 11-21 pp.

Roinila, Mika. Finns of interior B.C., Canada - Okanagan Valley: Case study. Siirtolaisuus, vol. 20, no. 1, 12-22 pp.

Tarkiainen, Kari. Finnarnas historia i Sverige. 1: inflyttarna från Finland och de finska minoriteterna under tiden 1809-1944 (History of the Finns in Sweden. 2: migrants from Finland and the Finnish minorities in 1809-1944). 1993. 445 pp. Finska historiska samfundet, Helsingfors and Nordiska Museet, Stockholm. ISBN 951-8915-72-5 and ISBN 91-7108349-9.

Virtanen, Timo. Somalipakolaiset Suomessa: tutkimus somalipakolaisten tulosta ja vas- 
taanotosta Suomeen (Somali refugees in Finland: a study on the arrival and reception of Somali refugees in Finland). Sosiaali- ja terveysministeriön julkaisuja 1993, no. 3. 1993. 102 pp. Sosiaali- ja terveysministeriö, Helsinki. ISBN 951-47-7322-5.

Virtanen, Timo. Somalipakolaiset Suomessa (Somali refugees in Finland). Siirtolaisuus, vol. 20 , no. $2,13-17$ pp.

\section{Internal migration}

Jutikkala, Eino. Suomalainen oppi taas vaeltamaan kauas (The Finns learned again to move far). In: Suomalaisten tarina, 1. Heräämisen aika 1860-1900, edited by Jaakko Itälä et al. 1993. 82-85 pp. Kirjayhtymä, Helsinki. ISBN 951-263830-4.

Jutikkala, Eino. Maassamuutto jatkuu entisellään (Internal migration continues as before). In: suomalaisten tarina, 2. Etsijäin aika 1901-1936, edited by Jaakko Itälä et.al. 1993. 34-36 pp. Kirjayhtymä, Helsinki. ISBN 951-268321-2.

Karjalainen, Elli. Muuttoliike ja muuttajan arvot (Migration and migrants values). In: Kainuun tulevaisuus - vaihtoehdot ja strategiat, Osa I, edited by Pentti Malinen. Research Reports 106. 1991. 68-77 pp. University of Oulu, Research Institute of Northern Finland, Oulu.

Karjalainen, Elli. Migration and its effects on areal development in Kuhmo 1959-84. In: Rural development, edited by M.C. Faus-Pujol and A. Higueras-Arnal. 1992. 107-124 pp. University of Zaratoga, Department of Geography and Spatial Organization, Spain.

Karjalainen, Elli. Muuttoliike Sotkamossa 1986-88 (Migration in Sotkamo 1986-1933). Siirtolaisuus, vol. 20, no. 1, 1993, 23-28 pp.

Kiuru, Pertti. Maassamuuton yhteiskunnalliset vaikutukset (The societal effects of internal migration). Liiketaloustieteellisen tutkimuslaitoksen julkaisuja, sarja B, no. 91. 1993. 77 + 45 pp. Liiketaloustieteellinen tutkimuslaitos, Helsinki. ISBN 951-8900-68-X.

Kumpulainen, Mikko. Maallemuuttajat: tutkimus Joensuusta ympäristökuntiin suuntautuvista muutoista (Rural in-migrants: study on the moves from Joensuu to the neighboring municipalities). 1993. 157 pp. Joensuun yliopisto, Joensuu. ISBN 951-708-127-8. Sum in Eng.

Parkkinen, Pekka. Alueellinen muuttoliike ja väestön ikääntyminen (Regional migration and population aging). VATT Discussion $\mathrm{Pa}$ pers, no. 40. 1992. 44 pp. Government Institute for Economic Research, Helsinki. ISBN 951561-052-4. Sum in Fin and Eng.

Salomaa, Heimo. Tilastoselvitys muuttoliikkeestä Vaasan läänissä 1980-luvulla = statistikutredning om flyttningsrörelsen i Vasa län på 1980-talet. Sarja B, no. 60. 1992. 153 pp. Vaasan läänin seutukaavaliitto, Vaasa. ISBN 952-9624-18-2.

\section{J. CHARACTERISTICS}

Alasuutari, Päivi. Ehkäisyn kiellon synty ja umpikuja vanhoillislestadiolaisessa herätysliikkeessä (The ban on birth control in the Old Laestadian revivalist movement). Sosiologia, vol. 29 , no. $2,1992,106-107$ pp.

Asp, Erkki (ed.). Ethnic minorities: three articles on the Macedonians in Bulgaria, the Kashubes in Poland and the Lapps in Finland. Sociological Studies, Series A, no. 20. 1993. 48 pp. University of Turku, Department of Sociology and Political Research, Sociological Studies, Turku. ISBN 951-880-964-X.

Asp, Erkki. The Lapps as a minority group in Finland. In: Ethnic minorities, 1993, 30-48 pp.

Karjalainen, Elli. Population aging, work and retirement in the United States. Aluesuunnittelu, vol. 20, no. 1, 1991, 14-15 pp.

Karjalainen, Elli. Väestön vanheneminen maantieteellisenä tutkimuskohteena (Population aging from the geographical point of view). In: Gerontologian päivät, 4, Suomen Akatemian vanhenemisen tutkimusohjelma, edited by Societas Gerontologia Fennica r.y. \& Kasvun ja vanhenemisen tutkijat r.y. 1992. Helsinki.

Karjalainen, Elli. Change in the population structure in Finland. Yearbook of Population Research in Finland, vol. 31, 1993, 81-90 pp.

Karjalainen, Elli. Väestön ikääntyminen alueellisena ilmiönä Suomessa $=$ population ageing as a regional phenomenon in Finland. Research reports, no. 111. 1993. 143 pp. University of Oulu, Oulu. ISBN 951-42-3549-5.

Lallukka, Seppo. Tverinkarjalainen väestöromahdus (The population collapse of Tver Karelians). Suomen Antropologi, vol. 17, no. 3, 1992, 59-72 pp.

Sarv, Heno. Suomalais-ugrilaisten kansojen väkiluku Venäjällä 18.-20. vuosisadalla (Population size of the Finno-Ugrian peoples in Russia in the 19th and 20th centuries). Kotiseutu, no. 4, 1992, 147-151 pp.

Stoyanova-Boneva, Bonka. "Pirin Macedonians" as a sociopsychological category. In: Ethnic minorities, 1993, 7-12 pp.

Synak, Brunon. The Kashubes and their ethnic-cultural identity. In: Ethnic minorities, 1993, 13-29 pp.

\section{K. DEMOGRAPHIC AND ECONOMIC INTERRELATIONS AND NATURAL RESOURCES}

Hietala, Kari. Maahanmuuton vaikutukset (The effects of immigration). Työpoliittinen tutkimus, no. 36, 1992. 129 pp. + app. Työministeriö, Helsinki. ISBN 951-47-6876-0.

Kauhanen, Ritva. Luoteis-Lapin väestö ja elinkeinot (The population of northwestern Lapland and economic activity). Sarja A, no. 118. 1992. $50+12$ pp. ISBN 951-9236-78-3. 
Lehto, Eero. Pienet ikäluokat - suuret eläkkeet (Small age groups - high pensions). TTT Katsaus, vol. 20, no. 4, 1992, 14-25 pp.

Lindgren, Jarl. Demographic Trends and the Pension Problem in Finland. IIASA working paper, no. WP-92-30. 1992. 30 pp. International Institute for Applied Systems Analysis (IIASA), Laxenburg, Austria.

Paananen, Seppo. Työvoimaa rajan takaa (Foreign labor force). Työpoliittinen tutkimus, no. 54. 1993. 146 pp. Työministeriö, Helsinki. ISBN 951-47-8141-4. Sum. in Eng.

Parkkinen, Pekka. Educational expenditures in Finland up to the year 2030. Yearbook of Population Research in Finland, vol. 31, 1993, 91-103 pp.

\section{DEMOGRAPHIC AND NONECONOMIC INTERRELATIONS}

Turpeinen, Oiva. Terveys-Suomen hauraat juuret (The beginning of health-care in Finland). In: Suomalaisten tarina, 1. Heräämisen aika 1860-1900, edited by Jaakko Itälä et. al. 1993. 64-68 pp. Kirjayhtymä, Helsinki. ISBN 951-263830-4.

Turpeinen, Oiva. Kansantautien valta taittuu - lapset erityissuojeluun (The diminishing of widespread diseases - increased protection for children). In: Suomalaisten tarina, 2. Etsijäin aika 1901-1936, edited by Jaakko Itälä et.al. 1993. 19-22 pp. Kirjayhtymä, Helsinki. ISBN 951-26-3831-2.

\section{POPULATION AND FAMILY POLICIES}

Auvinen, Riitta. Challenges facing future housing policy. Yearbook of Population Research in Finland, vol. 31, 1993, 111-124 pp.

Lindgren, Jarl. The influence of supportive family policies on family size: Sweden and Finland. Planned Parenthood in Europe, vol. 22, no. 2, 21-22 pp.

Ollila, Eeva. Taistelu väestöräjähdystä vastaan (The battle against population explosion). Sosiaalilääketieteellinen Aikakauslehti, vol. 29, no. 5-6, 1992, 300-305 pp.

Svenska Finlands folkting. Svenskfinland och befolkningspolitiken (The Swedish speaking Finns and population policy). Finlandssvensk rapport, no. 19. 1991. 10 pp. Svenska Finlands folkting, Helsingfors.

\section{P. PROFESSIONAL MEETINGS AND CONFERENCES}

Väestöliitto. Revival of ageing societies: proceedings of the International Population Conference "Revival of Ageing Societies", Espoo, Finland, September 2-4, 1992. 1992. 194 pp. Helsinki. ISBN 951-9048-98-7.

\section{Q. BIBLIOGRAPHIES, DIRECTORIES AND OTHER INFORMATION SERVICES}

Domander, Minna. Siirtolaisuus- ja pakolaistutkimus Suomessa 1980-1993 (Bibliography and report on research of immigration and refugees in Finland). 1993. 250 pp. Siirtolaisuusinstituutti, Turku. ISBN 951-9266-46-1.

Mattila, Ulla-Maija. Bibliography of Finnish Population Research 1991. Yearbook of Population Research in Finland, vol. 30, 1992, 104-109 pp.

Mattila, Ulla-Maija. Bibliography of Finnish Population Research in Finland 1992-1993, vol. 31, 1993, 125-130 pp.

\section{S. OFFICIAL STATISTICAL PUBLICA- TIONS}

\section{Official Statistics of Finland, Statistics Finland, Helsinki}

\section{Population statistics}

\section{Causes of death}

Kuolemansyyt $=$ causes of death 1991. Health 1992, no. 8. 107 pp. In Fin, Eng with sum in Eng.

\section{Economic activity}

Väestön taloudellinen toiminta $1990=$ befolkningens ekonomiska verksamhet $=$ economic activity of the population. Population census 1990, vol. 1. 1993. 321 pp. In Fin, Swe, Eng with sum in Eng. ISBN 951-47-7032-3.

Otostietoja työvoimasta ja työmatkoista 1990 (Sample information on labor force and commuting 1990). Population 1992, no. 5 and Population Census 1990, vol. 10. 69 pp. ISBN 951-47-6007-7.

\section{Family}

Asuntokunnat ja perheet $1990=$ bostadshushåll och familjer = household-dwelling units and families. Population census 1990, vol. 3. 1993. 288 pp. In Fin, Swe, Eng with sum in Eng. ISBN 951-47-7588-0.

Perheet $1990=$ familjer 1990. Population 1992, no. 7. 76 pp. In Fin and Swe with sum in Eng.

\section{International migration}

Korkiasaari, Jouni. Siirtolaisuus- ja ulkomaalaistilastot (Statistics on migration and aliens). Population 1992, no. 8.82 pp. Statistics Finland, Helsinki and Institute of Migration, Turku. 951-47-7582-1. 


\section{Life tables}

Honkanen, Ossi. Kuolleisuus- ja eloonjäämistauluja = dödlighets- och livslängdstabeller $=$ life tables 1986-90. Population 1993, no. 5. $32 \mathrm{pp}$. In Fin, Swe, Eng with sum in Swe and Eng.

\section{Population size}

Väkiluku kunnittain ja suuruusjärjestyksessä = befolkning kommunvis och i storleksordning 31.12.1992 (Population by the size of municipality). Population 1993, no. 6. In Fin, Swe.

\section{Population structure}

Taajamat $1990=$ tätorter $=$ localities. Population Census 1990, vol. 11. 1992. 145 pp. In Fin, Swe, Eng with sum in Eng. ISBN 951-476528-1.

Väestörakenne $=$ befolkningens sammansättning $=$ structure of population 1991. Population 1992, no. 11. 128 pp. In Fin, Swe with sum in Eng.

Väestörakenne 1992 = befolkningens sammansättning $=$ structure of population. Population 1993, no. 11. 144 pp. In Fin, Swe with sum in Eng.

\section{Projections}

Väestöennuste kunnittain = befolkningsprognos kommunvis $=$ population projection by municipalities 1991-2020. Population 1992, no. 6. 104 pp. In Fin, Swe, Eng with sum in Eng.

Väestöennusteet $=$ befolkningsprognoser $=$ population projections 1993-2030. Population 1993, no. 10. 37 pp. In Fin, Swe, Eng with sum in Eng.

\section{Vital statistics}

Väestönmuutokset $=$ befolkningsrörelsen $=$ vital statistics 1990. Population 1993, no. 4. 116 pp. In Fin, Swe, Eng with sum in Eng.

Väestönmuutokset kunnittain = befolkningsrörelsen kommunvis $=$ vital statistics by municipality 1991. Population 1993, no. 3. 61 pp. In Fin, Swe, Eng with sum in Eng.

\section{Population statistics and projections by other institutions}

Miettinen, Anneli. Population data on Finland 1900-1991. Yearbook of Population Research in Finland, vol. 30, 1992, 110-120 pp.

Miettinen, Anneli. Population data on Finland. Yearbook of Population Research in Finland, vol. 31, 1993, 133-142 pp.

National Agency for Welfare and Health. Tilastoja syntyneistä $1990=$ statistics on births in Finland 1990. Terveys 1992, no 6. 54 pp. In Fin, Eng.
Meriläinen, Jouni; Gissler, Mika; Hemminki, Elina; Teperi, Juha. Perinataalitilastot 1989 = Finnish perinatal statistics $1989.1993 .51 \mathrm{pp}$. STAKES National Research and Development Centre for Welfare and Health, Helsinki.

Svenska Finlands Folkting. Finlandssvenskarna 1990: en statistisk översikt (Swedish speaking Finns: a statistical report). Finlandssvenska rapport, no. 20. 1992. 47 pp. Helsingfors. ISBN 951-95204-8-1.

Väestörekisterikeskus. Suomen poissaoleva väestö 1.1.1992 = Finlands frånvarande befolkning 1.1.1992 (Expatriate Finns on January 1, 1992). 1992. $25+4$ pp.

Väestörekisterikeskus. Suomen asukasluku = Finlands invånartal 1.1.1992 (Number of inhabitants in Finland). 1992. 42 pp. Helsinki. In Fin, Swe.

Väestörekisterikeskus. Suomen asukasluku = Finlands invånartal 1.1.1993. 1993. 42 pp. Helsinki. In Fin, Swe.

\section{Sources}

The collections of the library of the Population Research Institute of Väestöliitto The Finnish databases KATI and KOTI The US database POPLINE

Nordic Demography, vol. 19, 1992/93

Population Index, vol. 58, 1992, nos. 1-4 and vol. 59, 1993, nos. 1-2

Index

Alasuutari, P. - J
Aro, S. - F
Asp, E. - J
Auvinen, R. - M
Björcklund, K. - H1
Brancker, A. - E
Csernak, M. - G
Domander, M. - H1, Q
El-Khorazaty, N. F
Engman, M. - H1
Erkkola, R. - F
Finnäs, F. - G
Finnäs, F. - C
Gissler, M. - S
Haavio-Mannila, E. - G
Hemminki, E. - F, S
Hietala, K. - K
Honkanen, O. - S
Hulkko, J. - A, G
Jakobson, L. - C
Jutikkala, E. - E, D, H2
Karjalainen, E- B, F, J, H2
Kauhanen, R. - K
Keskimäki, I. - F
Kiuru, P. - H2
Kontula, O. - F
Korkiasaari, J. - H1, S
Kosunen, E. - F


Kultalahti, O. - H1

Kumpulainen, M. - H2

Lallukka, S. - J

Lehto, E. - K

Leino, P. - E

Leitzinger, A. - H1

Lindeman, S. - E

Lindgren, J. - D, G, M, K

Lutz, W. - D, F

Lähteenmäki, P. - F

Maanantaiseura - D

Majava, A. - A

Makkonen, K. - F

Martelin, T. - E

Martikainen, P. - E

Mattila, U.-M. - Q

Maunula, M. - F

Meriläinen, J. - S

Miettinen, A. - G, S

Myhrman, A. - F

National Agency for Welfare and Health $-\mathrm{S}$

Nerdrum, M. - G

Nieminen, A. - G

Nieminen, M. - D

Nikander, T. - G

Notkola, I.-L. - F

Notkola, V. - D, E

Ojala, T. - H1

Ojanlatva, A. - F

Ollila, E. - M

Paananen, S. - K

Parkkinen, P. - H2, K

Peltola, O. - C
Pennanen, V. - D

Pitkänen, K.J. - E

Prinz, C. - D

Raitis, R. - F

Rasimus, A. - F

Reijo, M. - C, E

Rimpelä, A. - E, F

Rimpelä, M. - F

Ritamies, M. - F, G

Roinila, M. - H1

Rytkönen, H. - E

Saari, M. - G

Saarinen, R. - F

Salomaa, H. - H2

Sarv, H. - J

Savela, S. - E

Seppelin, M. - C

STAKES - F

Statistics Finland - S

Stoyanova-Boneva, B. - J

Svenska Finlands folkting - M, S

Synak, B. - J

Tarkiainen, K. - H1

Teperi, J. - F, S

Turpeinen, O. - L

Uitto, J.I. - A

Uutela, A. - F

Valkonen, T. - C, E

Virtanen, T. $-\mathrm{H} 1$

Vuorinen, H. - E

Väestöliitto - P

Väestörekisterikeskus - S

Väisänen, E. - E 